\title{
PARACHUTE AND LATERAL PROPPING REACTIONS IN PRETERM CHILDREN
}

\author{
Lygia Ohlweiler ${ }^{1}$, Alexandre R. da Silva ${ }^{2}$, Newra T. Rotta ${ }^{3}$
}

\begin{abstract}
A non-controlled, prognostic cohort study was performed with the aim of establishing markers of neurological development and defining a clinical and epidemiological profile of preterm newborns at 3, 6, 9, and 12 months of gestation-corrected age in terms of parachute and lateral propping reactions. Newborns with gestational age of up to 36 weeks and 6 days, weighing 2,000 g or less at birth, were included in the study At 6 months of age, parachute and lateral propping reactions were present in $8.1 \%$ of the patients. At 9 months, the parachute reaction was present in $87.5 \%$, and the lateral propping reaction was present in $90 \%$ of the children. It was possible to assess parachute and lateral propping reactions in preterm children in the first year of life. Alterations in trunk-limb coordination may be evidenced in the 1st year of life through postural reactions, which are maintained as prematurity markers until school age.
\end{abstract}

KEY WORDS: psychomotor performance, parachute, lateral propping, preterm newborn.

\section{Reações de paraquedismo e apoio lateral em crianças prematuras}

\begin{abstract}
RESUMO - Com o objetivo de traçar um perfil clinico-epidemiológico e estabelecer marcos do desenvolvimento neurológico de recém-nascidos prematuros aos 3, 6, 9 e 12 meses de idade corrigida, quanto às reações do paraquedismo e do apoio lateral, foi realizado estudo de coorte não controlado, com enfoque prognóstico. Foram incluídos no estudo recém-nascidos com idade gestacional até 36 semanas e 6 dias, com 2000g ou menos de peso ao nascimento. As reações do paraquedismo e apoio lateral estavam presentes em 8,1\% aos 6 meses, em 87,5\% e 90\% respectivamente aos 9 meses. Foi possível avaliar as reações posturais do paraquedismo e do apoio lateral em crianças prematuras no periodo de um ano. Alterações na coordenação tronco-membros pode ser evidenciada no $1^{\circ}$ ano de vida através de reações posturais, que são mantidas como marcadores de prematuridade até a idade escolar.
\end{abstract}

PALAVRAS-CHAVE: desenvolvimento neurológico, paraquedismo, apoio lateral, recém nascido prematuro.

Prematurity is a risk factor for impaired neurological development. Even so, 80 to $90 \%$ of preterm children develop normally, provided no brain-compromising events occur ${ }^{1-3}$. Among several risk factors for neurologic impairment, asphyxia and peri and intraventricular hemorrhage are especially important, due to their potential for causing neurological damage. The effect of perinatal anoxia on the central nervous system (CNS) depends on gestational age: in preterms, perinatal anoxia affects subcortical regions, and in term newborns, cortical regions. The presence of subependymal germinative matrix, which is richly vascularized and vulnerable to $\mathrm{O}_{2}$ variations in preterms, explains the variable location of this type of lesion ${ }^{4,5}$. The maturation of balance reactions requires a minimal knowledge of the body. Such knowledge is acquired through the exercise of laby- rinthine reflexes, and generally of all reflexes, as well as through the accumulation of an adequate amount of impressions received from peripheral receptors, which allow the child to outline a sketch of the surrounding world. At 6 months, the child is already aware of his/her own body. There is a growing interest in hand movements, and gradually the hands change from toys to tools: the child is able to try efficacious balance reactions that involve a complex interrelation of the sensorial (proprioceptive, visual, and vestibular), cerebellar, and cortical pathways $5^{6,7}$.

The parachute reaction occurs when the baby is suspended ventrally and dropped suddenly with the head directed towards a table. This prompts a defensive reaction in which the upper limbs are extended and the hands are opened in order to prevent the fall. This reflex appears starting at 6 months of age ${ }^{7-9}$.

Department of Pediatrics, School of Medicine, Universidade Federal do Rio Grande do Sul; and Pediatric Neurology Unit, Hospital de Clínicas de Porto Alegre, Porto Alegre RS, Brazil: ${ }^{1}$ Assistant Physician; ${ }^{2}$ Resident; ${ }^{3}$ Professor.

Received 15 May 2002, received in final form 11 July 2002. Accepted 19 July 2002.

Dr. Lygia Ohlweiler - Avenida Pirapó 71/702 - 90470-450 Porto Alegre RS - Brazil - FAX: 55-51-311-1447. E-mail: fp54@terra.com.br. 
Lateral propping usually appears between 6 and 8 months of age, when the child is able to sit without assistance. If the infant is pushed sideways with an abrupt shove on one shoulder while sitting, s/he extends the appropriate arm and puts his/her open hands over the support plane near the legs or in the angle formed by them.

The evolutional neurological evaluation (ENE) at 7 years of age in a group of preterms showed a statistically significant alteration in trunk-limb coordination in relation to term children ${ }^{10}$; other studies assessing school-age children born at term have also observed unaltered trunk-limb coordination ${ }^{11,12}$. Our work aimed at verifying whether alterations in trunk-limb coordination can be observed in the 1st year of life in preterm children. For that, we described the clinicalepidemiological profile of preterm newborns at 3, 6, 9 , and 12 months of gestation-corrected age in terms of the parachute and lateral propping reactions.

\section{METHOD}

This study was designed as a non-controlled cohort study. The factor under study was prematurity and its clinical effect on postural reactions. The sample was composed of preterm newborns born at Hospital de Clínicas de Porto Alegre, Brazil, from August 1995 to November 1998.

Children were followed for one year. They were assessed in the preterm clinic at 3, 6, 9, and 12 months of age (corrected for 40 weeks of gestation). A detailed neurological evaluation was carried out, including assessment of neuropsychomotor and language development, of the lateral propping and parachute reactions, and auditory and visual evoked potentials. Babies born with a gestational age of up to 36 weeks and 6 days, weighing 2,000 $\mathrm{g}$ or less, and who fulfilled the inclusion criteria were selected for the study. Gestational age was determined by Ballard's method ${ }^{13}$.

Exclusion criteria were: Apgar score $<8$ at the 5 th minute, cerebral hemorrhage, seizures, alterations in consciousness, CNS lesions, congenital infections, genetic syndromes, and prenatal intoxication. Newborns presenting clinical intercurrences that could interfere with neurological development, such as severe sepsis, jaundice requiring exsanguination transfusion, and use of mechanical ventilation for more than 7 days were also excluded. In addition, children who presented intercurrences that could interfere with CNS development, such as seizures, traumatic brain injury with neurological symptoms, infection of the CNS, and altered neurological evaluation were excluded in the follow-up period. The results were analyzed using the EpiInfo and SPSS softwares.

\section{RESULTS}

Forty preterm newborns who fulfilled the inclusion criteria were assessed; $56.2 \%$ were female.
Table 1. Distribution of newborns according to gestational age.

\begin{tabular}{lcc}
\hline Gestational age (weeks) & $\mathrm{n}$ & $\%$ \\
\hline$<30$ & 10 & 25 \\
$30-34$ & 19 & 45.5 \\
$>34$ & 11 & 27.5 \\
Total & 40 & 100 \\
\hline
\end{tabular}

Table 2. Distribution of newborns according to birthweight.

\begin{tabular}{lcc}
\hline Birthweight $(\mathrm{g})$ & $\mathrm{n}$ & $\%$ \\
\hline$<1000$ & 11 & 27.5 \\
$1000-1500$ & 18 & 45 \\
$>1500-2000$ & 11 & 27.5 \\
Total & 40 & 100 \\
\hline
\end{tabular}

Table 3. Intercurrences in preterm newborns.

\begin{tabular}{ll}
\hline Intercurrence & $\%$ \\
\hline Mild jaundice & 92.3 \\
Sepsis & 82.5 \\
Apneas of prematurity & 56.4 \\
Use of continuous positive airway pressure & 42.5 \\
Mechanical ventilation & 28.9 \\
\hline
\end{tabular}

Mean maternal age was $29 \pm 7.9$ years. Gestational age was $30-34$ weeks for $45.5 \%$ of the babies, and less than 30 weeks for $25 \%$ (Table 1 ). Concerning birthweight, $45 \%$ presented low weight, and $27.5 \%$ presented extremely low weight (Table 2). Intercurrences during the neonatal period were mild jaundice (92.3\%), followed by sepsis ( $82.5 \%)$, and apneas of prematurity (56.4\%) (Table 3); mean hospitalization time was 44 days. From 6 to 9 months we observed a major increase in the percentage of infants presenting parachute and lateral propping reactions (Table 4). We observed a similar frequency for the parachute and lateral propping reactions in all gestation-corrected ages ( $3,6,9$, and 12 months); there were small differences resulting from the fact that some children missed one of the four evaluations.

\section{DISCUSSION}

Lateral propping and parachute reactions are a normal part of development. These postural reactions involve both the labyrinth and vision; however, it seems that the reaction is actually triggered by the visual stimulus, since blind children have been 
Table 4 . Appearance of postural reactions and static balance according to the age.

\begin{tabular}{cccc}
\hline $\begin{array}{c}\text { Gestation-corrected } \\
\text { age (months) }\end{array}$ & $\begin{array}{c}\text { Parachute } \\
\text { reaction (\%) }\end{array}$ & $\begin{array}{c}\text { Lateral propping } \\
\text { reaction (\%) }\end{array}$ & $\begin{array}{c}\text { Sitting without } \\
\text { assistance (\%) }\end{array}$ \\
\hline 3 & 0 & 0 & 0 \\
6 & 8.1 & 8.1 & 10.8 \\
9 & 87.5 & 90 & 95 \\
12 & 100 & 100 & 100 \\
\hline
\end{tabular}

shown to take more time to develop it ${ }^{7}$. Capute et al. ${ }^{14}$ and Blasco ${ }^{15}$ emphasize the distinction between primitive reflexes and postural reactions. Primitive reflexes are triggered by sensorial stimuli, and they are highly stereotyped. The connections that are necessary for these reflexes are subcortical, located in the brain stem. Cortical maturation inhibits brain stem reflexes - they start to appear at 25 weeks of gestation and remain clinically evident until 3 to 6 months of life.

Postural reactions, on the contrary, are not true reflexes; they require cortical maturity. These movements are less stereotyped, and require a complex interrelation between cortical, cerebellar, and sensorial (proprioceptive, visual, and vestibular) pathways. Lateral propping and parachute reactions are observed from 6 months of age on. Our sample of preterms is considered at low risk for neurological impairment - despite the low birthweight and gestational age - because they did not experience any events that could interfere with neurological development. Even so, wefound lateral propping and parachute reactions in only $7.5 \%$ of the children studied.

Amiel-Tison and Grenier ${ }^{9}$ report that lateral propping reaction appears when the child is able to sit without assistance; to Coriat ${ }^{7}$, it manifests itself when the child still requires assistance to sit, and reappears in special cases, after the child acquires the ability to sit without assistance. We consider the lateral propping reaction a postural reaction (not a reflex) for the maintenance of trunk balance; only at 12 months of age did all children in our sample present these reactions.

Balance is maintained through a complex physiologic mechanism, in which the osteoarticular system, proprioceptive sensitivities, cerebellar and vestibular functions have important roles $^{6}$. The development of static balance in the 1st year of life requires maturation of this mechanism; at 6 months of age, $50 \%$ of the children sit unsupported, and at 9 months, $100 \%$ have acquired this ability ${ }^{16}$. In our sample of preterm newborns, only $10.8 \%$ sat unsupported at 6 months of age, and $95 \%$ at 9 months.

Postural reactions are mechanisms acquired to help balance maintenance. In this study, postural reactions were observed to appear late in most children, at 9 months of age (Table 3). Trunk and limb dyskinesia, which implies axial musculature dysfunction, is more visible when there is involvement of the cerebellar vermis, responsible for trunk balance. We conclude that alterations in trunk-limb coordination may be evidenced in the 1st year of lifethrough postural reactions, which are maintained as prematurity markers until school age.

\section{REFERENCES}

1. Aylward GP, Pfeiffer SI, Wright A, Verhulst SJ Outcome studies of low birth weight infants published in last decade: a metaanalysis. J Pediatr 1989;118:512-520.

2 Escobar GJ, Littenberg B, Petitti DB. Outcome among surviving very low birthweight infants: a meta-analysis. Arch Dis Child 1991;66:204-211.

3. Allen MC . The high-risk infant. Pediatr Clin N Am 1993;40:479-489.

4. Volpe J. Current concepts of brain injury in the premature infant. Am J Roentgenol 1989;153:243-251.

5. Weindling, M. Periventricular haemorrhage and periventricular leukomalacia. Br J Obstet Gynaecol 1995;102:278-281.

6. Thomas A, Saint-Anne Dargassies S. Le nouveau-né normal. In Études neurologiquessur lenouveau-néetlejeunenourrisson. Paris: Masson, 1952.

7. Coriat LF. Maturação psicomotora no primeiro ano de vida da criança. 3.Ed. São Paulo: Moraes, 1991.

8. Paine RS, Brazelton TB, Donovan DE, Drorbaugh JE, Hubbell JP, Sears $M$. Evolution of postural reflexes in normal infants and in presence of chronic brain syndromes. Neurology 1964; 4:1036-1048.

9. Amiel-Tison C, Grenier A. Neurologic evaluation of the newborn and the infant. New York: Masson, 1983.

10. Ohlweiler L, Alfano L, Rotta N T. Evolutional neurologic evaluation of seven year -old children born prematurely. Arq Neuropsiquiatr 1996; 54:369-374.

11. Rotta NT. Exameneurológico evolutivo edificuldadeno aprendizado. Arq Neuropsiquiatr 1975;33:132-139.

12. Rotta NT, Guardiola A. Aspectos clínicos de la disfuncion cerebral mínima. An Neuroped Latinoamericana 1989;1:59-69.

13. Ballard J L, Khoury JC, Wedig K, Wang L, Eilers-Walsman BL, Lipp R. New Ballard Score, expanded to include extremely premature infants. J Pediatr 1991;119:417-423.

14. Capute AJ, Shapiro BK, Accardo PJ. Motor functions: associated primitive reflex profiles. Dev Child Neurol 1982;24:662-669.

15. Blasco PA. Primitive reflexes: their contribution to the early detection of cerebral palsy. Clin Pediatr1994;33:388-397.

16. Diament AJ. Exame neurológico do lactente. In Diament AJ, Cypel S (Eds.). Neurologia infantil, 3.Ed. São Paulo: A theneu, 1996. 